\title{
POTENTIAL PROTEIN DEPOSITION IN THE EUROPEAN WILD BOAR (Sus scrofa L.)
}

\author{
Roberto P. Quijada ${ }^{1}$, and Suzanne M. Hodgkinson ${ }^{\text {* }}$
}

The growth rate of farmed European wild boars (Sus scrofa L.) is perceived to be very slow. However, there is no available information on the genetic potential of these animals in terms of potential lean tissue growth.The aim of the study was to determine the maximum capacity for protein deposition (operational PDmax) in wild boars under controlled environmental conditions. Four diets were formulated containing different levels of digestible energy (DE): 2.2, 2.4, 2.6, and 2.8 Mcal $\mathrm{DE} \mathrm{kg}{ }^{-1}$. All of the diets contained at least $5 \mathrm{~g}$ lysine per Mcal DE. Twenty purebred wild boars from a commercial farm of the same age $( \pm 4 \mathrm{~d})$ and with an initial liveweight of $27 \pm 0.50 \mathrm{~kg}$ (mean \pm standard error of the mean) were used in the study. At the beginning of the study (day 1), four animals were sacrificed and the carcasses were frozen without the digestive tract contents. The remaining animals were divided in foursomes and received each of the four diets over a $28-\mathrm{d}$ period; they were then sacrificed and the carcasses were frozen without the digestive tract contents. All of the carcasses were ground and analyzed for DM, crude protein, ether extract, and ash. Protein deposition of the animals sacrificed on day 28 was determined as the difference between crude protein content estimated for the animals on day 1 using data from the animals sacrificed on day 1 and protein content of animals sacrificed on day 28. It was not possible to determine PDmax due to the genetic heterogeneity of the animals. Further studies on PDmax in wild boars must be carried out following genetic selection and breeding to produce more homogeneous animals.

Key words: Protein deposition, digestible energy, wild boar.

$\mathrm{M}$ eat from European wild boar (Sus scrofa L.) is commercialized in Chile for a select clientele. Potential export markets have also been identified such as the European Union and Asia (de la Vega, 2003; Skewes and Martínez, 2004).

It is believed that the potential growth rate of these animals is not being observed in production systems, which delays their delivery to the market. Most animals are produced using a semi-extensive production system (Skewes and Morales, 2006). In these systems, the growth rate of wild boars normally ranges between 150 and 200 $\mathrm{g} \mathrm{d}^{-1}$ (Sudom et al., 2001; de la Vega, 2003; Skewes et al., 2008). It is important to highlight the fact that, until now, these animals have only been subjected to natural selection and their growth potential is unknown.

For animal growth to occur, animals must receive more nutrients than they require for maintenance. The energy from the nutrients can be used to accumulate lean and/ or fat tissue in the animal's body (Sandberg et al., 2005a; 2005b). Protein deposition (PD) is an indicator of lean tissue accumulation in the animal's body (van Milgen et al., 2008).

${ }^{1}$ Universidad Austral de Chile, Facultad de Ciencias Agrícolas, Instituto de Producción Animal, Casilla 567, Valdivia, Chile. "Corresponding author (shodgkin@uach.cl).

Received: 1 July 2011.

Accepted: 17 May 2012.
In the domestic pig, it has been estimated that protein makes up approximately $32 \%$ of the body mass (Cromwell, 1998). Using this value, along with the maximum daily growth rates of wild boars in commercial farms of approximately $200 \mathrm{~g} \mathrm{~d}^{-1}$, it can be estimated that the current PD is probably around $64 \mathrm{~g} \mathrm{~d}^{-1}$.

The objective of this study was to determine the potential maximum PD rate (operational PDmax) of the European wild boar. This value can then be used as a reference for the genetic capacity of lean tissue deposition of European wild boars currently being farmed.

\section{MATERIALS AND METHODS}

The digestible energy (DE) values necessary for the diets were calculated based on wild boar with a mean live weight of $27 \mathrm{~kg}$. The maintenance requirement for wild boars was estimated by considering that they are the same species as the domestic pig, and with the NRC (1998) equation for domestic pig growth $\left(\mathrm{ED}=110 \mathrm{kcal} \times \mathrm{PV}^{0.75}\right)$ a value of 1.3 Mcal DE d ${ }^{-1}$ was obtained for these animals. The DE contents of the diets were calculated as 1.9, 2.1, 2.3, and 2.5 times maintenance to support mean growth rates of $200 \mathrm{~g} \mathrm{~d}^{-1}$, PD of $64 \mathrm{~g} \mathrm{~d}^{-1}$ for diet 1; $218 \mathrm{~g} \mathrm{~d}^{-1}$, PD of $70 \mathrm{~g}$ $\mathrm{d}^{-1}$ for diet 2; $236 \mathrm{~g} \mathrm{~d}^{-1}$, PD of $76 \mathrm{~g} \mathrm{~d}^{-1}$ for diet 3; and $255 \mathrm{~g}$ $\mathrm{d}^{-1}$, PD of $82 \mathrm{~g} \mathrm{~d}^{-1}$ for diet 4 , respectively. As a result, four diets were formulated (Table 1), which differed in their levels of digestible energy (DE) and lysine (Table 2) with 
Table 1. Composition of experimental diets.

\begin{tabular}{|c|c|c|c|c|}
\hline Ingredients & Diet 1 & Diet 2 & Diet 3 & Diet 4 \\
\hline & \multicolumn{4}{|c|}{$\longrightarrow \mathrm{g} \mathrm{kg}^{-1}$} \\
\hline Corn & 50 & 140 & 240 & 420 \\
\hline Barley meal & 100 & 50 & 50 & 0 \\
\hline Soybean meal & 100 & 150 & 200 & 320 \\
\hline Sunflower meal & 100 & 100 & 100 & 100 \\
\hline Soybean oil & 10 & 10 & 10 & 10 \\
\hline Wheat bran & 140 & 100 & 100 & 20 \\
\hline Fishmeal & 50 & 50 & 50 & 50 \\
\hline Alfalfa meal & 400 & 350 & 200 & 30 \\
\hline Calcium carbonate & 10 & 10 & 10 & 10 \\
\hline Salt & 10 & 10 & 10 & 10 \\
\hline Vitamin/mineral mix & 30 & 30 & 30 & 30 \\
\hline
\end{tabular}

Table 2. Nutrient and energy content of experimental diets (dry matter basis).

\begin{tabular}{|c|c|c|c|c|}
\hline & Diet 1 & Diet 2 & Diet 3 & Diet 4 \\
\hline Dry matter, $\mathrm{g} \mathrm{kg}^{-1}$ & 875.1 & 878.3 & 876.9 & 883.1 \\
\hline Total ash, $\mathrm{g} \mathrm{kg}^{-1}$ & 100.6 & 95.8 & 83.4 & 67.4 \\
\hline Crude protein, $\mathrm{g} \mathrm{kg}^{-1}$ & 251.4 & 257.0 & 261.4 & 283.6 \\
\hline Gross energy, Mcal kg-1 & 4.36 & 4.46 & 4.45 & 4.59 \\
\hline Calculated digestible energy, $\mathrm{Mcal} \mathrm{kg}^{-1}$ & 2.2 & 2.4 & 2.6 & 2.8 \\
\hline Crude fat, $\mathrm{g} \mathrm{kg}^{-1}$ & 40.6 & 45.4 & 43.4 & 45.4 \\
\hline Crude fiber, $\mathrm{g} \mathrm{kg}^{-1}$ & 113.0 & 110.5 & 87.0 & 38.0 \\
\hline \multicolumn{5}{|l|}{ Amino acids, $\mathrm{g} \mathrm{kg}^{-1}$} \\
\hline Lysine & 13.1 & 11.8 & 13.7 & 17.1 \\
\hline Arginine & 14.4 & 12.3 & 19.4 & 20.4 \\
\hline Histidine & 5.6 & 5.0 & 6.4 & 7.5 \\
\hline Isoleucine & 10.4 & 9.4 & 11.5 & 13.4 \\
\hline Leucine & 16.7 & 15.8 & 18.3 & 22.6 \\
\hline Methionine & 3.8 & 4.7 & 3.7 & 4.4 \\
\hline Cysteine & 3.2 & 3.9 & 3.3 & 3.8 \\
\hline Phenylalanine & 10.9 & 10.1 & 11.5 & 14.0 \\
\hline Tyrosine & 7.6 & 6.6 & 8.6 & 9.8 \\
\hline Threonine & 8.5 & 8.0 & 8.7 & 10.0 \\
\hline Valine & 13.1 & 12.3 & 13.5 & 15.6 \\
\hline Aspartic acid & 25.3 & 22.9 & 26.4 & 30.2 \\
\hline Glutamic acid & 36.2 & 32.4 & 44.1 & 50.6 \\
\hline Serine & 7.5 & 6.8 & 8.2 & 9.1 \\
\hline Proline & 18.1 & 18.3 & 15.8 & 16.7 \\
\hline Glycine & 12.2 & 11.5 & 12.2 & 13.5 \\
\hline Alanine & 11.9 & 11.7 & 11.7 & 14.2 \\
\hline
\end{tabular}

diet 1: 2.2 Mcal DE kg-1, $1.06 \%$ lysine; diet 2: $2.4 \mathrm{Mcal}$ $\mathrm{DE} \mathrm{kg}{ }^{-1}, 1.15 \%$ lysine; diet 3: $2.6 \mathrm{Mcal} \mathrm{DE} \mathrm{kg}{ }^{-1}, 1.2 \%$ lysine; and diet 4: 2.8 Mcal DE kg-1, $1.4 \%$ lysine. These lysine contents were calculated based on the assumption that the animals required $0.12 \mathrm{~g}$ truly digestible lysine per gram of protein deposition (NRC, 1998).

The study used 20 purebred wild boars from a commercial farm of the same age $( \pm 4$ d) and with a liveweight of $27 \pm 0.5 \mathrm{~kg}$ (mean \pm standard error of the mean, SEM); they had been housed and fed under the same conditions before the study.

The animals were kept in eight $1.2 \mathrm{~m} \times 2.0 \mathrm{~m}$ pens (allowing individual feeding via pen subdivision) in a chamber with a concrete floor maintained at a temperature of $18 \pm 1{ }^{\circ} \mathrm{C}$ and $12 \mathrm{~h}$ of light per day. Water was always available to the animals throughout the study.

In order to accustom the animals to the new environment, routine, and management, they were fed individually with a commercial diet for $8 \mathrm{~d}$, which was offered at a rate of $10 \%$ of their metabolic body weight (liveweight $\left.{ }^{0.75}\right)$ per day divided into two meals $(08: 30 \mathrm{~h}$ and 16:30 h). This diet contained (determined values; dry matter base) $4.27 \mathrm{Mcal} \mathrm{kg}^{-1}$ gross energy, $190 \mathrm{~g} \mathrm{~kg}^{-1}$ crude protein, $79 \mathrm{~g} \mathrm{~kg}^{-1}$ crude fiber, and $15 \mathrm{~g} \mathrm{~kg}^{-1}$ crude fat.

After this time, animals were weighed and four were randomly selected and sacrificed to obtain body composition data at the beginning of the study (day 1). Animals were sedated with azaperone $\left(4 \mathrm{mg} \mathrm{kg}^{-1} \mathrm{LW} \mathrm{im}\right)$ and then anaesthetized with sodium pentobarbital $(1 \mathrm{~g} 25$ $\left.\mathrm{kg}^{-1} \mathrm{LW}\right)$ administered via the ear vein. The entire digestive tract of each animal was then removed, opened, and the contents were washed out with water. The digestive tracts were added to the carcasses which were then weighed and frozen.

The remaining 16 animals were randomly allocated to experimental diets 1 to 4 with four animals per diet. The animals received their diets individually as $10 \%$ of their metabolic bodyweight (liveweight ${ }^{0.75}$ ) per day divided into two meals $(08: 30 \mathrm{~h}$ and 16:30 h). Animals were weighed every $7 \mathrm{~d}$ and the quantity given to each animal was adjusted according to the new liveweight. On day 28 , these animals were sacrificed and their digestive tract cleaned as previously described.

All of the carcasses were weighed and the back fat thickness at the $\mathrm{P} 2$ site (at the $10^{\text {th }}$ rib, $6.3 \mathrm{~cm}$ ventrally from the spine) was manually measured. Each carcass was passed through an industrial grinder (FMC 2 td., model $N^{\circ} 2161$, serial 6242, Melbourne, Australia) four times and a $2 \mathrm{~kg}$ sample was taken from each carcass. Each sample was freeze-dried and ground again (ThomasWiley, Laboratory Mill, model 4). Samples were then analyzed for DM, crude protein (CP, Kjeldahl method), crude fat (ether extract), and ash (AOAC, 1996).

Diet samples were also analyzed for DM, gross energy (GE, bomb calorimeter), $\mathrm{CP}$, crude fat, crude fiber (CF, method 978.10 of AOAC; AOAC, 1996), and ash (AOAC, 1996). Amino acid content of the diet samples was determined by sample hydrolysis (5 to 7 $\mathrm{mg}$ ) in $1 \mathrm{~mL}$ of $6 \mathrm{molL}^{-1} \mathrm{HCl}$ containing $0.1 \%$ phenol for $24 \mathrm{~h}$ at $110 \pm 2{ }^{\circ} \mathrm{C}$ in vacuum-sealed glass vials. Amino acid concentrations were determined with Waters High Performance Liquid Chromatography (HPLC) calibrated against reference amino acids. The Maxima 820 (Waters, Millipore, Milford, Massachusetts, USA) software individually identified the amino acids by their retention time, and compared them to the reference samples. Since acid hydrolysis partially destroys cysteine and methionine, they were determined following sample oxidation ( 3 to $4 \mathrm{mg}$ ) with $1 \mathrm{~mL}$ of performic acid (one part $30 \% \mathrm{H}_{2} \mathrm{O}_{2}$ and nine parts $88 \%$ formic acid) for 16 $\mathrm{h}$ at $0{ }^{\circ} \mathrm{C}$. Tryptophan is also partially destroyed by acid hydrolysis and was not determined.

Total protein content of the experimental animals on day 1 was estimated based on the assumption that their protein concentration was the same as that of the control animals, that is, the mean $\mathrm{CP}$ concentration of the control animals (sacrificed on day 1). Protein deposition (PD) of each experimental animal $\left(\mathrm{g} \mathrm{d}^{-1}\right)$ was calculated as the 
difference between the estimated total protein content of the experimental animal on day 1 (the animal's liveweight multiplied by the mean protein concentration of the animals sacrificed on day 1) and that determined on day 28 (CP content $\times$ animal weight) divided by 28 . Fat deposition $\left(\mathrm{g} \mathrm{d}^{-1}\right)$ of the experimental animals was calculated in a similar manner.

Digestible energy (DE) content of each diet was calculated by adding the DE content of each ingredient in each diet with data from NRC (1998) and Hodgkinson et al. (2008). The DE intake of each animal was calculated by multiplying the DE content of each diet by the total diet consumption of each diet for each animal.

All statistical analyses were carried out with SAS software (version 9.1.3, SAS Institute, 2006), using fitted a completely randomized experimental design. A linearplateau relationship was fitted the individual DE intakes and PD data (PROC NLIN) to determine the energy intake of the animals when they reached PDmax. A regression analysis was also carried out with the same data.

An ANOVA was carried out to determine whether there were differences between animals receiving each diet for the following: initial liveweight, final liveweight, carcass weight, growth rate, backfat thickness, mean feed intake, total DE intake, protein deposition, fat deposition, and carcass concentrations of $\mathrm{CP}$, ash, and crude fat (DM basis). A probability of $\mathrm{P}<0.05$ was considered statistically significant. The data was tested for normality before analysis by the KolmogorovSmirnov test.

\section{RESULTS}

The nutritional composition and amino acid profile of the experimental diets are shown in Table 2. All diets contained similar quantities of amino acids with lysine being the first limiting amino acid in each diet.

All animals remained healthy throughout the study and consumed all of their dietary allowances. They showed an overall mean weight gain of $167 \pm 24 \mathrm{~g} \mathrm{~d}^{-1}$ (mean \pm SEM).

The variables evaluated in wild boars that were fed experimental diets are shown in Table 3. There were no significant differences between animals from each treatment, except for the daily and total DE dietary consumption where animals on diets 1, 2, and 3 did not significantly differ, while those receiving diet 4 consumed a higher amount of DE.

The chemical composition of the animal carcasses showed no significant differences between animals receiving different diets (Table 4).

The individual DE intake of the animals ranged from 2.65 Mcal DE d $\mathrm{d}^{-1}$ to $4.13 \mathrm{Mcal} \mathrm{DE} \mathrm{d}^{-1}$. The PD ranged from -3.9 to $66.6 \mathrm{~g} \mathrm{~d}^{-1}$, and the animal with the highest PD (66.56 $\left.\mathrm{g} \mathrm{d}^{-1}\right)$ consumed 4.13 Mcal DE d $\mathrm{d}^{-1}$. However, higher DE intake was not always related to higher PD; for example, animals that consumed approximately $3.3 \mathrm{Mcal}$ $\mathrm{DE} \mathrm{d}^{-1}$ had PDs ranging from -13 to $65 \mathrm{~g} \mathrm{~d}^{-1}$.

It was not possible to fit a linear-plateau relationship to $\mathrm{DE}$ intake and PD data since there was too much spread of data. Regression between DE intake and PD was not significant $\left(r^{2}=0.044\right)$ and there was no apparent relationship between individual energy intakes and PD (Figure 1).

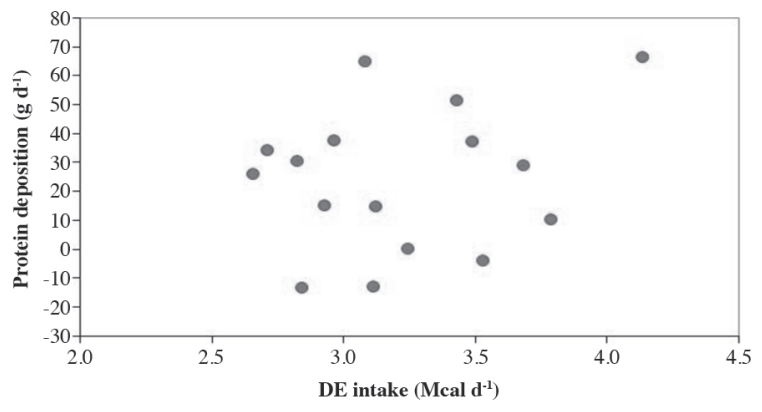

Figure 1. Protein deposition and mean digestible energy (DE) intake of wild boars that received experimental diets $\left(r^{2}=0.044\right)$.

Table 3. Variables evaluated in wild boars that received experimental diets (mean $\pm \operatorname{standard}$ error, $n=4)$.

\begin{tabular}{|c|c|c|c|c|c|}
\hline Variables & Diet 1 & Diet 2 & Diet 3 & Diet 4 & $\mathrm{P}$ \\
\hline Initial live weight, $\mathrm{kg}$ & $26.9 \pm 0.94$ & $27.9 \pm 1.65$ & $25.7 \pm 1.65$ & $28.7 \pm 1.50$ & NS \\
\hline Final live weight, $\mathrm{kg}$ & $30.7 \pm 1.23$ & $31.1 \pm 1.93$ & $31.0 \pm 2.76$ & $35.2 \pm 1.64$ & NS \\
\hline Slaughtered weight, $\mathrm{kg}^{*}$ & $29.8 \pm 1.24$ & $30.9 \pm 1.79$ & $30.2 \pm 2.60$ & $35.2 \pm 1.69$ & NS \\
\hline Daily food intake, $\mathrm{kg}$ & $1.28 \pm 0.03$ & $1.28 \pm 0.06$ & $1.23 \pm 0.08$ & $1.35 \pm 0.05$ & NS \\
\hline Daily DE intake, Mcal animal $\mathrm{d}^{-1}$ & $2.9 \pm 0.06 \mathrm{a}$ & $3.0 \pm 0.13 \mathrm{a}$ & $3.2 \pm 0.19 \mathrm{a}$ & $3.8 \pm 0.14 b$ & $* * *$ \\
\hline Total DE intake, Mcal animal $^{-1}$ & $81.15 \pm 1.44 \mathrm{a}$ & $84.66 \pm 3.55 \mathrm{a}$ & $86.96 \pm 5.23 \mathrm{a}$ & $103.73 \pm 3.79 b$ & $* * *$ \\
\hline Growth rate, $\mathrm{g} \mathrm{d}^{-1}$ & $134 \pm 62$ & $116 \pm 33$ & $186 \pm 46$ & $232 \pm 41$ & NS \\
\hline Protein deposition, $\mathrm{g} \mathrm{d}^{-1}$ & $24.6 \pm 16.32$ & $7.1 \pm 8.46$ & $30.1 \pm 11.93$ & $36.0 \pm 11.68$ & NS \\
\hline Fat deposition, $\mathrm{g} \mathrm{d}^{-1}$ & $20.2 \pm 14.54$ & $37.7 \pm 22.25$ & $25.3 \pm 22.30$ & $44.5 \pm 5.73$ & NS \\
\hline Backfat thickness, mm & $6.3 \pm 0.88$ & $11.1 \pm 2.44$ & $6.4 \pm 2.11$ & $10.4 \pm 0.47$ & NS \\
\hline
\end{tabular}

${ }^{*}$ Weight of slaughtered animal corresponds to the whole animal without digestive tract content; P: Probability; NS: Non significant $(\mathrm{P}>0.05)$; $* * *$ P $<0.001 ;$ DE: digestible energy.

Table 4. Carcass composition of wild boars that received experimental diets (mean \pm standard error, dry matter basis, $n=4)$.

\begin{tabular}{|c|c|c|c|c|c|c|}
\hline & Control & Diet 1 & Diet 2 & Diet 3 & Diet 4 & $\mathrm{P}$ \\
\hline $\mathrm{DM}, \mathrm{g} \mathrm{kg}^{-1}$ & $957.2 \pm 4.1$ & $964.1 \pm 1.4$ & $959.7 \pm 3.5$ & $959.6 \pm 4.5$ & $960.9 \pm 1.5$ & NS \\
\hline $\mathrm{CP}, \mathrm{g} \mathrm{kg}^{-1}$ & $458.7 \pm 12.2$ & $465.9 \pm 20.1$ & $431.5 \pm 24.3$ & $468.1 \pm 36.5$ & $442.3 \pm 14.4$ & NS \\
\hline Ash, $\mathrm{g} \mathrm{kg}^{-1}$ & $82.1 \pm 4.8$ & $89.5 \pm 5.0$ & $98.4 \pm 12.2$ & $98.9 \pm 7.7$ & $96.6 \pm 7.3$ & NS \\
\hline Crude fat, $\mathrm{g} \mathrm{kg}^{-1}$ & $397.7 \pm 4.9$ & $400 \pm 25.3$ & $432.0 \pm 39.4$ & $374.3 \pm 42.2$ & $410.8 \pm 12.9$ & NS \\
\hline
\end{tabular}

DM: dry matter; CP: crude protein; P: probability; NS: non significant $(\mathrm{P}>0.05)$. 


\section{DISCUSSION}

This study was carried out in an attempt to determine the typical PDmax of European wild boars currently being raised in Chile. The PDmax of the wild boar has not been previously studied, although it has been amply studied in the domestic pig (e.g., Kyriazakis and Emmans, 1992; van Milgen et al., 2000). Only daily growth rates have been previously determined for the wild boar (Sudom et al., 2001; de la Vega, 2003; Skewes et al., 2008), which resulted in lower values than for the domestic pig; this is probably due to both genetic and environmental factors. Moreover, it is important to note that the genetic variability of the wild boar has not been studied.

The methodology used in this study has been successfully used for studies with the domestic pig and is considered as an established method (Whittemore and Fawcett, 1976; Chiba et al., 1991a; 1991b; van Milgen et al., 2000; van Milgen and Noblet, 2003). It is based on using a group of control animals that represent the animals at the beginning of the study. The control animals are sacrificed on day 1 of the study, and the whole empty body of the animal (whole body excluding digestive tract contents) is ground and analyzed to determine body composition for $\mathrm{CP}$, crude fat, and ash. It is assumed that information from control animals is valid as a baseline (due to the genetic homogeneity among domestic pigs) with the rest of the animals that are sacrificed at the end of the study. The PD of each animal is determined as the difference between the animals processed at the end of the study and those processed on day 1 .

The present study used same methodology as the one described for the domestic pig. However, PD was negative in some cases, even though the animals had grown. This may have been due to differences in the actual protein composition of individual animals on day 1 as compared with the control animals. Animals registering a negative PD may have actually had a greater CP content on day 1 than the control animals despite having the same age and having been fed and managed in the same way, thus resulting in an overestimation of their body protein content on day 1 . The ideal way to conduct this type of study in wild boars would be to measure protein content of the experimental animals on day 1 rather than using data from control animals. This could be done by the Dual Energy X-Ray Absorptiometry (DXA) technique, which has been used in the domestic pig (Scholz and Mitchell, 2003). This is a non-invasive tool to measure the tissue content of protein, fat, and bone mineral mass in the living (anaesthetized) animal, thus allowing determining body composition of each individual animal at the beginning and end of the study and improving the accuracy of the generated information. If this technology had been available, it would most likely have resulted in more precise individual values; however, it is important to highlight that given the degree of variation between the animals in the present study, comparing animals between treatments would most likely still show a high variability.

Animals were handled to provide the best possible feeding, management, and environmental conditions to let them express their genetic potential. Their diet consumption was regulated in accordance with their metabolic weight in order to mark the difference between treatments, but should have been very close to their ad libitum intake (Chiba et al., 1991a; 1991b) and with all the animals consuming their full daily allowance. On the other hand, the animals were not force-fed (Black et al., 1986; Emmans and Kyriazakis, 1997; van Milgen and Noblet, 2003). Diets were designed with lysine as the first limiting amino acid (confirmed via amino acid analysis), but with lysine quantities so that growth would be limited by the amount of energy in the diets rather than the quantity of amino acids.

In this study, the mean growth rate of all the animals was $167 \pm 24 \mathrm{~g} \mathrm{~d}^{-1}$ (mean $\left.\pm \mathrm{SEM}\right)$. Growth rates similar to the ones observed in animals receiving diets 3 and 4 in this study have been reported by Hodgkinson et al. (2009) and Weiler et al. (1998) with values of $227 \pm 10.6 \mathrm{~g} \mathrm{~d}^{-1}$ and $233 \mathrm{~g} \mathrm{~d}^{-1}$ (mean $\left.\pm \mathrm{SEM}\right)$, respectively. Lower growth rates have been reported by Hodgkinson et al. (2008) with values of $116 \mathrm{~g} \mathrm{~d}^{-1}$ that are similar to the values recorded for animals consuming diet 2 in this study.

The total daily energy requirements in the domestic pig are approximately 3 to 4 times their maintenance requirements (NRC, 1998). As mentioned above, wild boars have lower growth rates and it is estimated that the total daily energy requirements would likely be approximately 1.5 to 2.0 times their maintenance energy requirements. The digestible energy of the experimental diets was not determined in the assay, but the diets were formulated using DE values provided by the food chemical composition tables for the wild boar (Hodgkinson et al., 2008) and domestic pig (Degussa, 1996; FEDNA, 2003).

It appears that there is a very high level of genetic heterogeneity in the wild boar in accordance with the results obtained. The animals were approximately the same age (with a maximum of $4 \mathrm{~d}$ between births), from the same commercial farm, and had been raised under the same conditions. However, mean back fat thickness (Table 3) between treatments ranged from $6.25 \pm 0.88$ (diet 1) to $11.10 \pm 2.44$ (diet 2) with mean values of $6.38 \pm 2.11$ for diet 3 and $10.40 \pm 0.47$ for diet 4 ; there was no apparent relationship between greater back fat thickness and energy intake. As expected, the results were similar for total body fat accumulation (Table 3); standard error values were very high and, in some cases (e.g., diet 3), approached the size of the mean value. This supposed genetic variation is also very apparent in the spread of data (Figure 1).

High genetic homogeneity could be a positive attribute for research purposes since it suggests that the wild boar has a wide variety of genetic differences. Many of the genes that are still present in the wild boar are 
probably no longer present in the domestic pig because of the genetic erosion that occurred as they were bred to improve different traits. However, from the producer's point of view, this heterogeneity between wild boars is not desirable since it means that each animal will react differently to environments and diets and result in a much less homogeneous final product.

In the present study, the number of animals was relatively small; for some studies, this can explain why significant differences are not found between treatments, thus creating the false conclusion that treatments did not significantly affect the measured variables (Whitley and Ball, 2002). To estimate an adequate sample size, the equation by Zar (1999) can be used since it considers the degree of variation in the data. Applying this equation to the data generated in the present study (this is the first study of its type, so the inter-animal variation was previously unknown), the sample size required to identify any significant differences would be at least 225 animals per treatment. However, even if this study were repeated with this number of animals per treatment, there would still be a variation between animals reacting very differently in terms of their daily and maximum PD.

We found that the maximum PD could not be determined with the energy level provided by the experimental diets, there was no apparent relationship between DE intake and PD, and animals that consumed more energy did not necessarily grow at a faster rate or accumulate more protein than those with a lower DE intake (Figure 1). It is suggested that further studies about PD in European wild boars could be carried out through genetic selection and breeding to produce more homogeneous animals.

\section{CONCLUSION}

In the present study, it was not possible to detect the PDmax in the wild boar due to the high genetic heterogeneity of the animals.

\section{ACKNOWLEDGEMENTS}

This work was supported by a grant from the Fondo Nacional de Desarrollo Científico y Tecnólogico (FONDECYT) Project 1060190 . We would like to thank Procesadora de Carnes del Sur S.A., PROCASUR S.A. for allowing us to process the carcasses with their equipment.

\footnotetext{
Acumulación potencial de proteína en jabalí europeo (Sus scrofa L.). La tasa de crecimiento del jabalí Europeo (Sus scrofa L.) se considera muy baja. Sin embargo, no existe información respecto al potencial genético de estos animales en términos de aumento potencial de tejido magro. El objetivo del presente estudio fue determinar la capacidad de acumulación de proteína (PDmax operacional) en jabalíes bajo condiciones ambientales controladas. Se formularon cuatro dietas con distintos
}

niveles de energía digestible (ED: 2,$2 ; 2,4 ; 2,6 ;$ y 2,8 Mcal $\mathrm{ED} \mathrm{kg}^{-1}$. Todas las dietas contenían al menos $5 \mathrm{~g}$ lisina por Mcal ED. Veinte jabalíes puros de la misma edad $( \pm 4$ d) provenientes de un plantel comercial, con un peso vivo inicial de $27 \pm 0,5 \mathrm{~kg}$ (promedio \pm error estándar de la media) fueron utilizados en el estudio. Al inicio del estudio (día 1) se sacrificaron cuatro animales, y posteriormente se congelaron sin el contenido del tractodigestivo. El resto de los animales recibieron las dietas (cuatro animales por cada dieta) durante 28 d, después de los cuales también fueron sacrificados y se congelaron sin el contenido del tractodigestivo. Posteriormente todas las carcasas fueron molidas y analizadas para materia seca, proteína cruda, extracto etéreo, y cenizas. La acumulación de proteína de los animales sacrificados el día 28 fue determinada como la diferencia en el contenido de proteína cruda estimado para estos animales en el día 1 usando los datos de los animales sacrificados el día 1 y su contenido de proteína el día 28. En el estudio no se pudo determinar PDmax debido a la heterogeneidad genética de los animales. Estudios a futuro relacionados con PDmax en jabalíes podrían ser realizados después de efectuar una selección genética y cruzas para lograr animales más homogéneos.

Palabras clave: Acumulación de proteína, energía digestible, jabalí.

\section{LITERATURE CITED}

AOAC.1996. Official methods of analysis of Association of Official Analytical Chemists (AOAC) International. $16^{\text {th }}$ ed. AOAC International, Gaithersburg, Maryland, USA.

Black, J.L., G.T. Davies, H.J. Bray, L.R. Giles, and R.P. Chapple. 1986. Simulation of energy and amino acid utilisation in the pig. Research and Development in Agriculture 3:121-145.

Cromwell, G.L. 1998. Estudio crítico. Presentación de las recomendaciones nutricionales del NRC para porcino 1998. XIV Curso de Especialización Avances en Nutrición y Alimentación Animal. 17 p. University of Kentucky, Lexington, Kentucky, USA.

Chiba, L.I., A.J. Lewis, and E.R. Peo. 1991a. Amino acid and energy interrelationships in pigs weighing 20 to 50 kilograms: I. Rate and efficiency of weight gain. Journal of Animal Science 69:694-707.

Chiba, L.I., A.J. Lewis, and E.R. Peo. 1991b. Amino acid and energy interrelationships in pigs weighing 20 to 50 kilograms: II. Rate and efficiency of protein and fat deposition.Journal of Animal Science 69:708-718.

de la Vega, J. 2003. Las otras carnes en Chile: Características y consumo. 286 p. In J.A. de la Vega (ed.) Universidad Austral y Fundación para la Innovación Agraria (FIA), Valdivia, Chile.

Degussa. 1996. Degussa feed additives. AMINODat ${ }^{\circledR}$. Table of amino acids in feedstuffs. $4^{\text {th }}$ ed. Degussa A.G., Hanau-Wolfgang, Germany.

Emmans, G.C., and I. Kyriazakis. 1997. Models of pig growth: problems and proposed solutions. Livestock Production Science 51:119-129.

FEDNA. 2003. Programa de consulta tablas FEDNA 2003. $2^{\text {a }}$ ed. Fundación Española para el Desarrollo de la Nutrición Animal (FEDNA), Madrid, España. Available at http://www.fundacionfedna org/ingredientes-para-piensos (accessed 20 March 2011).

Hodgkinson, S.M., I. López, and S. Navarrete. 2009. Ingestion of energy, protein and amino acids from pasture by grazing European wild boar (Sus scrofa L.) in a semi-extensive production system. Livestock Science 122:222-226. 
Hodgkinson, S.M., M. Schmidt, and N. Ulloa. 2008. Comparison of the digestible energy content of corn, oats and alfalfa between the European wild boar (Sus scrofa L.) and Landrace $\times$ Large White pig (Sus scrofa domesticus). Animal Feed Science and Technology 144:167-173.

Kyriazakis, I., and G.C. Emmans. 1992. The effects of varying protein and energy intakes on the growth and body composition of pigs. 2. The effects of varying both energy and protein intake. British Journal of Nutrition 68:615-625.

NRC. 1998. Nutrients requirements of swine. 189 p. $10^{\text {th }}$ ed. National Research Council (NRC). National Academy Press, Washington DC., USA.

Sandberg, F.B., G.C. Emmans, and I. Kyriazakis. 2005a. Partitioning of limiting energy in the growing pig: description of the problem, possible rules and their qualitative evaluation. British Journal of Nutrition 93:205-212.

Sandberg, F.B., G.C. Emmans, and I. Kyriazakis. 2005b. Partitioning of limiting energy in the growing pig: testing quantitative rules against experimental data. British Journal of Nutrition 93:213224.

SAS Institute. 2006. Base SAS 9.1.3 Procedures Guide.Vols. 1, 2, 3 and 4. $2^{\text {nd }}$ ed. Statistical Analysis Systems Institute, Cary, North Carolina, USA.

Scholz, A.M., and A.D. Mitchell. 2003. Protein, fat, and bone mineral deposition rates in growing pigs (birth to $90 \mathrm{~kg}$ ) of different RyR1 genotypes studied by dual energy x-ray absorptiometry. In Souffrant, W.B., and C.C. Metges (eds.) Progress in Research on Energy and Protein Metabolism. EAAP Scientific Series 109:543548. European Federation of Animal Science (EAAP), Rome, Italy.

Skewes, O., y J. Martínez. 2004. Informe final del proyecto FDICORFO "Adaptación y optimización del sistema de producción porcina al aire libre (OutDoor) para la obtención de productos elaborados de Jabalí (Sus scrofa L.) orientada a la exportación hacia el mercado de la comunidad Europea”, Chillán, Chile. Fondo de Desarrollo e Innovación- Corporación de Fomento de la Producción (FDI-CORFO), Santiago, Chile.
Skewes, O., and R. Morales. 2006. Crianza del jabalí (Sus scrofa L.) en Chile. Distribución, tamaño y aspectos básicos de manejo. Agro-Ciencia 22:29-36.

Skewes, O., R. Morales, F. González, J. Lui, P. Hofbauer, and P. Paulsen. 2008. Carcass and meat quality traits of wild boar (Sus scrofa s. L.) with $2 n=36$ karyotype compared to those of phenotypically similar crossbreeds $(2 n=37$ and $2 n=38)$ raised under same farming conditions. 1. Carcass quantity and meat dressing. Meat Science 80:1200-1204.

Sudom, B., R. Nixdorf, G. Lopinski, and S. Dobbs. 2001. Wild board production. 25 p. Saskatchewan Agriculture and Food, Economic and Production Information for Saskatchewan Producers, Saskatchewan, Canada.

van Milgen, J., and J. Noblet. 2003. Partitioning of energy intake to heat, protein, and fat in growing pigs. Journal of Animal Science 81(E. Suppl. 2):E86-E93.

van Milgen, J., N. Quiniou, and J. Noblet. 2000. Modelling the relation between energy intake and protein and lipid deposition in growing pigs. Animal Science 71:119-130.

van Milgen, J., A. Valancogne, S. Dubois, J. Dourmad, B. Sève, and J. Noblet. 2008. InraPorc: A model and decision support tool for the nutrition of growing pigs. Animal Feed Science and Technology 143:387-405.

Weiler, U., R. Claus, S. Schnoebelen-Combes, and I. Louveau. 1998. Influence of age and genotype on endocrine parameters and growth performance: a comparative study in Wild boars, Meishan and Large White boars. Livestock Production Science 54:21-31.

Whitley, E., and J. Ball. 2002. Statistic review 4. Sample size calculations. Critical Care 6:335-341.

Whittemore, C.T., and R.H. Fawcett. 1976. Theoretical aspects of a flexible model to simulate protein and lipid growth in pigs. Animal Production 22:87-96.

Zar, J. 1999. Biostatistical analysis. Department of Biological Sciences. Northern Illinois University. $4^{\text {th }}$ ed. 663 p. Prentice Hall International, New Jersey, USA. 